\title{
EM NOME DO POVO ...
}

\author{
Goffredo da Silva Telles Junior \\ Professor Titular Aposentado da Faculdade de Direito \\ e Professor Emérito da Universidade de São Paulo
}

\begin{abstract}
Resumo:
A chamada "representação politica"; o problema do "mandato"; o imperativo ético da representação do povo nos parlamentos legislativos; o conceito de partido político; os partidos no Brasil; o problema da fidelidade partidária; os alvitres para a reforma partidária; pluralismo natural das fontes das normas, perpassando a discussão "povo e massa"; os grupos de pressão como centros de irradiação normativa; a questão da democracia participativa como anseio politico da atualidade; concluindo pela emenda constitucional necessária; são os tópicos discutidos em tom critico e reflexivo pelo emérito professor.
\end{abstract}

\begin{abstract}
:
The called "political representation", the problem of "mandato"; the ethical imperative of popular representation in the legislative parlaments; the concept of political party; the parties in Brazil; the probleme of party's fidelity; the hints to the party's reform; natural pluralism of the norm's sources, till the discussion "people and mass"; the pression's groups as centers of normative irradiation; the question of taking part democracy as politics wish of the present time, concluding with the necessary constitucional emendation, are the topics discussed in a critical and reflexive tone by the emeritus professor.
\end{abstract}

Unitermos: representação politica; mandato parlamentar; partido político; fidelidade partidária; povo e massa; democracia participativa; instituições representativas.

1. A chamada "representação política". O problema do "mandato" O imperativo ético da representação do Povo nos Parlamentos Legislativos.

Em nome do Povo, deve o Poder ser exercido. Por quê? Porque "todo o poder emana do povo" (Constituição, art. $\left.1^{\circ}\right)$.

Aqui, nestas linhas, o de que se vai tratar é, somente, do Poder do Povo na produção das leis: é da introdução da vontade dos governados nas lidas da elaboração legislativa oficial. 
Como se sabe, os governados participam do Poder Legislativo por meio de seus representantes, que são deputados, senadores e vereadores, todos eleitos por sufrágio universal.

Tal representação politica do Povo, pedra angular da Democracia, exige atenção especial.

Antes de mais nada, cumpre notar que toda representação resulta de um mandato.

Um mandato, como todos sabem, é o poder que uma pessoa, chamada mandante, atribui a outra pessoa, chamada mandatária, de praticar atos em nome do mandante. Consiste no poder de representar o mandante na execução desses atos.

$\mathrm{Na}$ ordem jurídica, o mandato implica necessariamente: 1 . a vinculação do mandatário às vontades e instruções do mandante (Código Civil, art. 1.289, §1 $\left.{ }^{\circ}\right) ; 2$. a obrigação do mandatário de prestar contas de seu desempenho (Código Civil, art. 1.301); 3. a possibilidade de revogação do mandato, por ato do mandante, salvo quando o contrário estiver convencionado no contrato, ou quando se verificarem os casos de exceção, mencionados na lei (Código Civil, art. 1.317).

Convém lembrar, desde logo, que os deputados, os senadores e os vereadores não se acham vinculados à vontade e instruções de seus eleitores, nem são obrigados à prestação de contas, nem podem ser destituídos (a não ser em casos de crime e de atentado ao decoro). Não são, pois, titulares de um mandato jurídico; não são mandatários ou representantes, no sentido técnico destes termos.

Que são eles? São delegados do povo; são titulares de uma delegação que o povo lhes atribuiu. São emissários a que o povo deu uma incumbência, un encargo. São cidadãos eleitos pelo processo do sufrágio universal, para que elaborem as leis - mas, note-se, as leis que eles próprios entenderem boas ou úteis. São enviados do eleitorado, sem dúvida, mas sem mandato jurídico.

Sem o vínculo do mandato jurídico, sem a responsabilidade jurídica do mandatário, sem o poder do mandante de revogar o mandato, é bem claro que a representação dos parlamentares não tem traço de representação juridica.

Kelsen adverte: "Para estabelecer uma verdadeira relação de representação, não basta que o representante seja nomeado ou eleito pelo representado. $\dot{E}$ necessário que o representante esteja juridicamente obrigado a executar a vontade do representado e que o cumprimento dessa obrigação seja garantido juridicamente" (Teoria Geral do Direito e do Estado, 2" parte, IV, B, g).

Nada tendo da representação jurídica, será legítimo considerar existente a chamada representação dos parlamentares?

Respondem os políticos que a representação dos parlamentares não é juridica, mas política, e que a representação política, embora não implicando os caracteres do mandato, é verdadeira representação em virtude do papel que os parlamentares desempenham no uso do Poder Legislativo.

O que os políticos sustentam, em suma, é o seguinte: o fato de não estar o legislador ligado por mandato a seus eleitores não significa que não esteja ligado por 
coisa nenhuma. Em verdade, dizem eles, o parlamentar está preso ao programa de seu partido. Ele é eleito para um determinado fim: para propugnar pela vitória das medidas anunciadas nesse programa. Tal fim ou objetivo, em razão do qual sua eleição é realizada, não confere, é certo, à missão do parlamentar, a natureza de um mandato, em sentido próprio, mas, na opinião dos políticos, faz, dessa missão, algo de semelhante a um mandato.

Pode acontecer, eventualmente, que o parlamentar se comporte em desacordo com o programa de seu partido. E, em verdade, é o que, na prática, sucede com certa freqüência. O parlamentar, como se sabe, não é obrigado, por lei nenhuma, a prestar contas a seu eleitorado, nem é responsabilizável por seus atos. Mas, embora não havendo responsabilidade jurídica do parlamentar, existe o que se chama responsabilidade política. Pode o parlamentar rebelde sofrer sanções diversas, como a censura de seus chefes e líderes, e até a expulsão de seu partido. Essa responsabilidade politica, portanto, não deixa de apresentar uma certa analogia com a responsabilidade jurídica.

Quanto ao poder de revogação do "mandato" do parlamentar, é incontestável que o eleitorado não tem tal faculdade, se esta for considerada pelo prisma do Direito Civil. Mas, na prática, a não-reeleição do parlamentar equivale à revogação de seu "mandato"

É evidente que tudo isso anda envolto em muita fantasia. Os teóricos se fundam no princípio de que os votos são dados aos candidatos em razão dos programas de seus respectivos partidos, e de que o parlamentar, uma vez eleito, está vinculado a esse programa. A experiência demonstra que, no Brasil e em outros países, nada disto se verifica.

Escreveu Miguel Reale: "Reconhecido o absurdo de se reduzir a representação à figura do mandato, é sabido que se resolveu dizer, quase como meio de contornar o problema, que se tratava de um mandato sui generis ou político. Do mandato conservou-se o nome por motivos pragmáticos e para atender a seu emprego

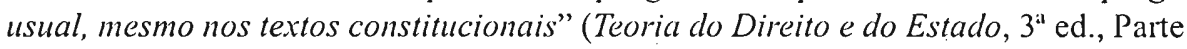
II, Cap. V, n. 44, nota 46).

Em verdade, o que acontece é o seguinte: embora sem mandato, destituidos dos poderes da representação autêntica, os parlamentares são chamados representantes para lembrar-lhes que se devem portar como se fossem, realmente, representantes e mandatários; como se a sua missão tivesse a natureza do mandato, cumprindo-lhes cuidar, em conseqüência, não de seus próprios interesses, mas dos interesses da coletividade.

O que se deseja, com o poder sugestivo de uma palavra, é conseguir na prática o que em teoria não é possível demonstrar. O que se quer é que os parlamentares se conduzam como verdadeiros representantes! Que sua ação vise somente ao que ele e seu partido programaram, em consonância com os anseios do povo!

No quadro de tais aspirações, proclamar que o regime político é representativo é firmar um preceito de dever, um principio moral. A palavra 
representação é mantida por um motivo deontológico, designando o que deve ser, ou o que deveria ser, a simbolizar, portanto, um ideal político.

Em suma, o regime político é dito representativo porque tem a intenção de ser representativo. É dito representativo porque deputados, senadores e vereadores se comportam (devem comportar-se) como se fossem, de fato, representantes de seus eleitores.

A representação nesse regime - a chamada representação politica - é uma esperança de representação, um anseio, um ideal.

Alto ideal este, porque no jogo político dos Parlamentos funciona como sistema de referência, como imperativo ético, a nortear as consciências dos legisladores.

Mas, evidentemente, tal sistema de referência, tal imperativo ético, tem maior ou menor eficácia conforme a qualidade moral dos legisladores e de seus respectivos partidos.

Esta última observação evidencia a grave responsabilidade do povo nos acertos e desacertos cometidos na escolha e eleição de seus legisladores.

A representação política pode ser um pensamento diretor, uma linha de conduta efetiva. Mas poder ser, eventualmente, o rótulo de uma farsa, de uma reles mentira, pode ser uma mistificação que, iludindo, enganando, embaindo povo e Nação, se torna causa direta da degringolada política de um País.

Parlamentos que se afastam dos anseios do povo, que legislam com displicência, ou que são apáticos, preguiçosos, ausentes, são Parlamentos que quebram os quadros de seu sistema de referência, violam o imperativo ético que é a razão de ser de sua existência, e perdem o excelso título de representantes politicos do povo.

2. O partido político: seu conceito.

O Congresso Nacional sempre foi reconhecido como o órgão por excelência da representação política.

Tribuna livre, poder crítico da política nacional, guarita da "eterna vigilância", caixa de ressonância de anseios e indignações, o Congresso Nacional, órgão excelso da elaboração das leis federais, se consagrou como a instituição mais característica da Democracia.

Pois bem, entre o Povo e o Congresso, existem os partidos politicos.

O conceito de partido político precisa logo ser fixado com clareza, para o perfeito conhecimento de sua razão de ser e de sua missão essencial, assim como para tornar possível a identificação e eventual rejeição e até cassação de agremiações espúrias, que se organizem e requeiram registro na Justiça Eleitoral, pretendendo operar com objetivos incompativeis com a natureza e os fins dos partidos autênticos.

Pinto Ferreira os definiu nos seguintes termos: "grupos sociais, geralmente regulados pelo direito público, vinculando pessoas que, tendo a mesma concepção sobre a forma desejável da sociedade e do Estado, se congregam para a conquista do poder politico, para efeito de realizar um determinado programa" (Teoria Geral do Estado, $2^{\circ}$ v., $8^{: "}$ parte, cap. LXVIII). 
Os partidos políticos são agrupamentos que se apresentam com um programa de aspirações de cunho social, e que, para realizá-lo, almejam eleger, apoiar ou combater, o presidente da República, os governadores dos Estados Federados, os prefeitos municipais, os senadores, os deputados e os vereadores. Querem ter arrimo popular e força política suficiente para conquistar o Poder, ou, ao menos, para decidir da nomeação e exoneração de ministros, de secretários de Estado e de outras autoridades do primeiro e segundo escalão do Governo Federal e dos Governos Estaduais e Municipais, assim como de chefes de autarquias e de empresas estatais, além de servidores públicos para cargos em comissão e para funções de confiança.

\section{Os partidos no Brasil. Problema: a fidelidade partidária.}

No Brasil, o que se vê é que os partidos, excetuada uma ou outra agremiação admirável, não têm desempenhado a missão que lhes é própria. Os partidos em geral não têm sido sempre os canais que deveriam ser. Para o povo, muitos partidos nada mais são do que siglas, meras siglas, só isto. E o povo os confunde, porque é imensa a balbúrdia das siglas.

O eleitorado - a multidão das cidades, das vilas, dos vilarejos e dos campos -- ignora o que muitos partidos colimam em benefício da coletividade. Desconhece os programas registrados na Justiça Eleitoral. Inoperantes programas esses, descartáveis no jogo político do regime vigente, freqüentemente esquecidos ou desacreditados, até mesmo por filiados dos partidos; até mesmo por muito deputado eleito! A verdade verdadeira é a de que muitos partidos, na consciência de inúmeros brasileiros, não se distinguem, uns dos outros, por sua história, nem pelo corpo de seus desígnios e fins, nem pelos motivos de sua razão-de-ser.O povo, o grande povo, o grande eleitorado de nosso País, sempre votou em personalidades, ou em candidatos apoiados por personalidades, ou num amigo, ou num amigo de amigos. Votou, muitas vezes, em ilusórias promessas de candidato em campanha eleitoral.

Nas últimas eleições, é certo, uma parte considerável do eleitorado pôde votar em defensores de um pensamento social definido; votou em representantes de um ideal devidamente proclamado, expresso com clareza no programa de um partido. Auspicioso acontecimento, sem dúvida! Até anos recentes, porém, o voto tem sido dado a pessoas - voto indiferente às idéias porventura expostas nos ignorados programas de partidos a que essas pessoas pertenciam; indiferente, muitas vezes, à falta de moralidade do candidato, no seu comportamento em tempos passados.

E os eleitos para o Congresso Nacional, eles próprios, com algumas notáveis exceções, permanecem despreocupados com as idéias e proposições dos olvidados programas. Doutrinariamente, não se acham vinculados a nada. Declaramse representantes do povo, no exercicio de um mandato. Mas, em verdade, não existe, entre os eleitos e seus eleitores, nem mandato autêntico, nem representação.

De fato, o que se tem verificado no Brasil, após as eleições, é o alheiamento de grande parte dos eleitos. Muitos dos chamados representantes se despegam dos que 
os elegeram, tomam as iniciativas políticas que bem entendem, sem prestação de contas a ninguém e sem escrúpulos de traição ideológica. Podem até mudar de partido, sem qualquer constrangimento, deixando sem "representante" o eleitor filiado ao partido largado.

A falta de um vínculo efetivo entre eleitos e eleitores ensejou o surgimento da malta dos falsos políticos, daqueles parlamentares já referidos, que são negligentes, improficuos, descuidados dos problema do País, movidos por interesses confusos, não bem explicados à Nação, às vezes desonestos.

Nessas circunstâncias, não é de estranhar que a fidelidade partidária tenha sido, no Brasil, um ideal bruxuleante, freqüentemente incógnito ou desconsiderado.

Esta lamentável realidade desmantela as molas cardiais da Democracia.

Se deputados e senadores não forem fiéis aos programas de seus partidos, se os partidos não forem instrumentos a serviço do bem comum e se rebaixarem à categoria de agremiações à disposição de ambições pessoais, então, políticos e partidos não estarão desempenhando o papel que lhes é inerente, numa Democracia autêntica.

Sem a fidelidade dos parlamentares aos ideários de interesse coletivo, definidos nos seus respectivos programas registrados, os partidos se reduzem a estratagemas indignos, a serviço de egoísmos disfarçados; e os políticos se desmoralizam.

Disse Miguel Reale: "Sem partidos ideologicamente distintos, não se pode estabelecer uma vida democrática verdadeira" (Histórias do Poder, depoimentos de diversos, Ed. 34).

É importante observar que, sem fidelidade aos programas dos partidos, a representação política no Parlamento não passa de mera ficção. É um manto de irrisão, atirado sobre os ombros do eleitorado. É logro; é uma pura farsa. É um triste faz-de-conta.

Ora, sem representação política autêntica, o regime político é de desdém pela vontade do povo. A própria Democracia, desligada do povo, passa a ser uma Democracia do faz-de-conta.

No Brasil de hoje, o Poder Legislativo ainda não parece um poder emanado do Povo. Destituído de representatividade, o Congresso Nacional, em seu conjunto, tem sido um poder resignado à subserviência ao presidente da República, vítima e cúmplice da usurpação de seu indeclinável Poder de legislar. Acolhendo, sem mostras de vergonha, "medidas provisórias" flagrantemente inconstitucionais, não tem desempenhado sua missão de Poder que atalha os abusos do Poder. Palco freqüente de escândalos, assembléia humilhada pelo descrédito popular, o Congresso Nacional, sem fidelidade partidária, vem exibindo sua forma de Democracia do faz-de-conta.

Roberto Romano disse: "Por falta de modificações estratégicas na condução do jogo politico e sem reformas que definam a estrita obediência dos representantes do povo aos programas dos partidos pelos quais foram eleitos, a luta eleitoral exibe, novamente, aspectos negativos do organismo politico" (Ética e fé pública, artigo na Folha de S. Paulo, em 15.03.2002). 
Nessas condições, a providência mais urgente, em hora de sinceridade, é a de alijar as contrafações de partidos, as excrescências e os vícios que maculam ou impedem a verdadeira representação política do povo nas Casas Legislativas do Governo.

O primeiro passo, a medida inadiável da Reforma Politica, aconselhada pela própria realidade brasileira, consiste em consagrar, em norma constitucional, o conceito democrático de partido político. Consiste em deixar firmada, nesse conceito, a relação necessária entre a atuação partidária e uma idéia programática do bem comum, uma idéia que é a razão de ser do partido, e que há de ser proclamada em seu programa registrado.

Convém não esquecer que os partidos, com a forma essencial que alcançaram no século XX, devem ser sempre "organizações a serviço de uma idéia" (Maurice Hauriou); "porta-vozes de uma doutrina" (Benjamim Constant); "formações que agrupam homens que têm as mesmas concepções" (Kelsen).

Disto se conclui que "nenhum partido deve ser tolerado se não persegue um ideal superior; se seu propósito não é o interesse coletivo, se só pretende apoderarse do governo" (Alfredo Palácios).

Não devem ser admitidas como partido as agremiações sem ideário próprio. Por exemplo, não podem ser admitidas como partido, as agremiações que vivem do aluguel de seus serviços de divulgação dos recados e alvitres de políticos de outros partidos - de políticos que maliciosamente se ocultam atrás do biombo da sigla fretada. Ou as agremiações que se deixam rebaixar a simples instrumento para o registro de qualquer candidato no Tribunal, sem consideração por seu programa político. Em verdade, tais agremiações não são partidos autênticos, porque não se enquadram no mencionado conceito de partido político. Tais agremiações são meras legendas de aluguel, artificios rasteiros, totalmente indiferentes quanto aos destinos do Estado. Seus registros no Tribunal precisam ser impedidos ou cancelados.

Para evitar desentendimentos, ou, talvez, confusões e tumultos, com eventuais contrafações partidárias, parece prudente rejeitar in limine os requerimentos de registro que não venham acompanhados de um rol de adesões em número igual ou superior a uma fixada porcentagem do total de eleitores nas circunscrições respectivas.

É claro que, em regime de partidos verdadeiros, o principio da fidelidade partidária constitui mandamento soberano, impondo obrigação de honra e de direito. Sua violação terá que acarretar, para o parlamentar, a perda do "mandato" Note-se bem: o costumeiro troca-troca de partidos não é compatível com o regime representativo da Democracia moderna.

Quando o autor da infidelidade ao ideário programático não é o parlamentar, mas é o próprio partido que, por decisão e conduta de seus líderes, transvia e deriva, mudando de direção e rumo, a condenação há de atingir, não o congressista demissionário, mas a agremiação transgressora. A infração deve ser denunciada em Plenário, e, nos casos de renitência, o registro do partido pode ser cancelado, a critério do Congresso. 


\section{Alvitres para a Reforma Partidária.}

Para dificultar a proliferação abusiva dos partidos; para assegurar o vínculo do eleito com seus eleitores; para garantir a vigência da fidelidade partidária, talvez o melhor, para o Brasil, seria um regime de cinco ou seis importantes partidos nacionais, com suas respectivas vocações ideológicas bem definidas, bem reveladas em seus programas. Alguns seriam o que hoje se costuma chamar de conservadores, e os outros seriam o que hoje se costuma chamar de progressistas. Se se quisesse conceituá-los de um modo simplista (sem rigor terminológico, mas em termos triviais, de fácil entendimento), dir-se-ia que a ala dos conservadores seria a dos partidos da direita, e que a ala dos progressistas seria a dos partidos da esquerda.

As duas alas haveriam de se distinguir com clareza, uma da outra. Distinguir-se-iam, essencialmente, pelo espirito. Distinguir-se-iam pelos principios que as definem e dirigem, isto é, pelos principios primeiros, que são superiores e anteriores a seus respectivos programas políticos, mas que os explicam e determinam. E distinguir-se-iam, finalmente, por seus programas, pelas suas decisões e atitudes, e até por seu estilo e comportamento.

Além deles, admitir-se-iam quatro ou cinco partidos menores, com objetivos estritos e delimitados, fixados em seus programas - como, por exemplo, o Partido Ruralista e o Partido Verde.

Nesse esquema, todos os partidos seriam falanges a serviço de um pensamento. Seriam portadores de definidas mensagens. Cada partido porfiaria na defesa de seus ideais de liberdade, igualdade e fraternidade, e, conseqüentemente, de suas concepções de sociedade e de ordem jurídica. Cada um inferiria, de seus próprios postulados, as soluções para os problemas enfrentados pelo Poder Legislativo.

Nessa anelada Democracia, as duas grandes facções do eleitorado nacional estariam devidamente representadas no Congresso Nacional: a facção das esquerdas estaria representada pelos deputados e senadores progressistas, empenhados nos pleitos do trabalho; e a facção das direitas, pelos deputados e senadores conservadores, empenhados nos interesses do capital.

E essa representação seria uma representação política autêntica. No dia da eleição, os cidadãos não seriam simplesmente igualados uns aos outros. Cada cidadão não seria apenas um eleitor, sem qualquer outra qualificação. Um eleitor não seria apenas um voto: um voto e só. Todo eleitor seria um cidadão pertencente a uma das facções do eleitorado: à facção da direita conservadora, ou à facção da esquerda progressista. Seria um cidadão optando por um ou por outro pensamento político, para o bem de seu País. E o conjunto dos eleitores deixaria de ser tido como um conglomerado indiviso, massa homogênea de votantes.

Essa representação seria autêntica, sem dúvida, porque os deputados se fariam mandatários de eleitores definidos. Os deputados e senadores do eleitorado conservador seriam representantes dos partidos da direita. Os deputados e senadores 
do eleitorado progressista - ou seja, trabalhista e socialista - seriam representantes dos partidos da esquerda.

E o que é preciso enfatizar, para prevenir contestações precipitadas, é que o sufrágio universal, nesta projetada Democracia, não seria o sufrágio universal cego, que reduz o povo à massa. O sufrágio universal, nessa Democracia, deixaria de ser cego, porque o eleitor votaria num pensamento, num ideal político, de que seu candidato é portador. Entre o eleitor e seu candidato, haveria um vínculo espiritual vínculo que permaneceria, entre o congressista e o cidadão que o elegeu, por todo o tempo do mandato.

É claro que, num tal regime, o principio da fidelidade partidária seria obrigação de honra, cuja violação acarretaria, para o parlamentar, a perda do mandato.

\section{Povo e massa.}

Indispensáveis, sim, os partidos políticos, no jogo pelo poder, nas Democracias modernas. Indispensáveis, em verdade, para a iniciativa das leis nos Parlamentos, e para todo o processo legislativo, de que trata a Constituição (Seção VIII). Indispensáveis, finalmente, para fiscalizar o cumprimento das leis, e para formar um Poder apto a refrear o Poder.

Mas, as simples realidades da vida - os fatos comuns do cotidiano político - revelam que, por mais que se proclamem "a voz do povo" "os portadores dos apelos da coletividade", os partidos, em sua quase totalidade, jamais realizam, efetivamente, o modelo, o ideal, que lhes é delineado pela pura doutrina, ou lhes é atribuído pela propaganda. Tentações eleitorais, alianças comprometedoras irresistiveis, fraquezas éticas, violações dos programas registrados, desídias parlamentares, até corrupções, tudo isto confere, antes de mais nada, ao complexo partidário, uma vida própria, movida por interesses corporativos ou egoísticos, muito separada da vida do povo e, não-raro, uma vida em conflito com os anseios da coletividade.

A verdade que salta aos olhos é a de que os partidos políticos - embora peças essenciais da Democracia - não logram exprimir a realidade pluralista e heterogênea da vida do povo, nas sociedades humanas.

A vida do povo... Esta, de fato, se desenrola numa infinidade de grupos sociais, que se organizam e desempenham suas missões à revelia dos partidos. Observese que os chamados delegados do povo nas Câmaras do Poder Legislativo - deputados, senadores, vereadores, todos filiados a partidos políticos - não se acham habitualmente vinculados a essas inúmeras entidades nas quais transcorre a vida real dos cidadãos; nas quais se trava a refrega comum de todos os dias, com suas aflições e necessidades, e também com suas alegrias e até triunfos.

Das atenções dos partidos, a maior parte dessa vida da população se acha excluida.

Referindo-se aos partidos brasileiros, e ao axioma de que "o povo participa do poder por meio dos partidos politicos", José Afonso da Silva neles denota 
"apenas uma visão teórica, cuja realização talvez seja uma simples miragem" (Currso de Direito Constitucional Positivo, $2^{\text {a }}$ parte, Título V, cap. IV, III, 12). Uma simples miragem! Impossível dizer melhor.

Sobre o assunto, muito ilustrativas são as seguintes proposições de Georges Burdeau: "Para denunciar o que se convencionou chamar 'o jogo estéril' dos partidos, o que se alega é que os partidos não constituem uma representação real da opinião. As forças vivas do pais estão alhures. Disto se conclui a inaceitabilidade de sua pretensão de se fazerem porta-vozes dos governados"

O que é preciso assinalar, com clareza, é que os partidos constituem uma só espécie do imenso gênero de grupos sociais existentes. Os políticos dos partidos não são delegados dessas outras entidades, de que a sociedade é feita. Tem razão Burdeau, quando afirma que os partidos não se podem outorgar o monopólio de representação da vontade nacional. É óbvio que esta vontade não se exprime, integralmente, pela voz dos partidos nos Parlamentos. Parte imensa dessa vontade se manifesta fora dos partidos e fora dos Parlamentos. Manifesta-se, como é sabido, nos grupos sociais em que a população efetivamente vive; nas instituições a que se vinculam os interesses existenciais das pessoas.

O povo é um todo, sim, mas um todo complexo, porque é composto de grupos sociais distintos, de comunidades diversas, de instituições discriminadas. $\mathrm{O}$ povo é um só todo, sim, mas um todo feito de partes diferentes; uma comunidade feita de comunidades; "uma instituição mais feita de instituições do que de individuos isolados", como disse Hauriou, em seu Compêndio de Direito Constitucional (1" parte, Cap. II, Seç̧ão $3^{\text {a }}, \S 2$ ). Em resumo, o povo é um todo essencialmente heterogêneo.

Povo não é massa.

A massa é homogênea. É una. Cada porção da massa é igual a todas as outras porções, como, por exemplo, as porções da massa do pão. Cada porção dessa massa é igual às outras porções.

O povo real, o povo constituído de seres humanos concretos, de pessoas com suas vidas individuais, vidas efetivamente vividas, esse povo complexificado, feito de grupos, de "corpos" sociais, não pode ser tratado como se fosse massa simplesmente.

Esta distinção entre povo e massa é fundamental na caracterização do Poder legítimo.

O povo - o Povo de que emana o Poder — não é um todo homogêneo, não é massa. O povo é uma entidade essencialmente heterogênea, feita de famílias, de escolas e universidades, de sindicatos e outras entidades de trabalhadores; de institutos de pesquisa e de centros de alta cultura; de associações da indústria, da agricultura e dos trabalhadores rurais; de uniões e centros de estudantes; de associações dos esportes; das agremiações de servidores públicos; de igrejas, de partidos, de ONGs, de sociedades de amigos, de entidades de serviços, de agrupamentos de minorias definidas.

É evidente que o desconhecimento dessa realidade fundamental impede o encontro do Poder Legislativo com a sociedade real - com a sociedade em que se 
desenrola a existência normal dos cidadãos. De fato, o povo sem mitos, sem ficções, o povo feito de grupos, de "corpos" sociais, não pode ser tratado como se fosse massa simplesmente. Ele nada tem a ver com as coletividades que se tenham conformado a ser massas humanas.

De massas humanas, é certo, não pode emanar o Poder legítimo. As massas são tangidas; não são fontes do Poder. Não há Democracia autêntica onde o povo é relegado à condição de massa.

6. Pluralismo natural das fontes de normas. Os grupos de pressão: centros de irradiação normativa.

Desde logo, cumpre observar que os grupos sociais, de que a sociedade global é constituída, são fontes inexauriveis de normas.

Primordialmente, tais grupos ou instituições são fontes de grande parte de suas próprias ordenações jurídicas, ou seja, de suas próprias normas constitutivas.

A ordenação constitutiva de um grupo - sua ordenação interna - é o que lhe confere a forma jurídica apropriada para a consecução de seus objetivos. Ela é a estrutura normativa em razão da qual o grupo é o que é: em razão da qual um sindicato tem a forma jurídica de um sindicato; uma sociedade mercantil, a forma jurídica de uma sociedade mercantil; uma universidade, a forma jurídica de universidade; um clube de futebol, a forma juridica de um clube de futebol. Ela é, também, a estrutura normativa fundamental de muitos relacionamentos da vida comum; ela pode ser um pacto antenupcial, ou uma convenção de condomínio, ou um contrato de locação, ou o contrato social de uma empresa; ou um contrato de venda e compra, ou qualquer outro tipo de contrato, escrito ou verbal, como estatutos, regimentos, regulamentos, etc.

É óbvio que os grupos não são fontes apenas de normas juridicas. As normas que regem a existência quotidiana das pessoas, e que dirigem seus passos a cada momento do dia, não são, em geral, mandamentos jurídicos. São normas de toda espécie, são imposições puramente morais, são usos e costumes, são práticas habituais, são modas nascidas da própria vida, isto é, nascidas nos grupos onde a vida se processa.

Pois bem, é precisamente dentro desse desabrochamento social que se elaboram e destacam as normas autorizantes, as normas jurídicas, que alguns autores denominam normas de garantia, que são, como se sabe, aqueles mandamentos que autorizam os lesados pela sua violação a exigir o seu cumprimento, ou a indenização pelos danos causados.

Não-raro, os interesses, em razão dos quais um grupo se constitui, só podem ser convenientemente protegidos se estiverem amparados, não apenas pela ordenação interna do grupo, mas, também, por normas jurídicas da sociedade global a que esse grupo pertence.

Então, o grupo passa a querer essas normas. Anseia por elas. E começa a trabalhar para obtê-las. Redigirá os competentes projetos e procurará dar-lhes as mais 
eloqüentes das justificações. Baterá às portas dos. Poderes Públicos para demonstrar a Justiça de suas pretensões e para solicitar que seus projetos sejam encaminhados aos órgãos legislativos do Estado. Enviará comissões ao Parlamento. Fará pedidos a meio mundo.

Desta maneira, os grupos atuam sobre o Governo, influenciam-no e com ele colaboram. Em virtude de sua própria natureza, fazem pressão sobre os poderes Públicos e funcionam como centros de irradiação normativa.

Em conseqüência, constituem-se em matrizes e mananciais de muitas ordenações juridicas da Nação.

Como são incontáveis os grupos organizados dentro de uma sociedade, inúmeras são as fontes de normas, e inúmeras as ordenações delas oriundas.

Eis porque a sociedade, considerada em seu todo, se apresenta, aos olhos do observador, como um imenso campo, onde desabrocham ordenações em todos os setores: E é enorme, em verdade, essa espontânea floração normativa.

Se se considerar o papel dos grupos sociais, como produtores de normas internas e como inspiradores e forças de pressão legislativa sobre os Poderes Públicos, não se pode deixar de reconhecer que tais grupos são, em verdade, fontes profundas e autênticas da ordenação jurídica nacional.

Esse pluralismo de fontes verdadeiras do Direito é uma das realidades primordiais das sociedades humanas.

Frise-se com deliberada insistência: esse pluralismo é uma realidade.

Não é uma hipótese, uma teoria, uma tese. É, isto sim, uma realidade objetiva, um fato, que não resulta da opinião ou da vontade de quem quer que seja, e que nem mesmo depende dos regimes políticos.

existe: eis tudo.

É uma realidade tão real como a própria vida dos homens. Tal pluralismo

Pois bem, essa realidade, precisamente, tem sido ignorada pelas fórmulas clássicas de representação do povo.

7. A Democracia Participativa: anseio político da atualidade.

O grande desafio, lançado aos constitucionalistas de nosso tempo, é precisamente este: o de descobrir a fórmula constitucional de assegurar a permanente penetração do pensamento e da vontade dos governados nas decisões dos governantes.

A Democracia ou é um sistema que garante a introdução dos anseios das entidades representativas da sociedade, nas decisões dos órgãos planejadores dos Governos, ou a Democracia perde o seu sentido. E é este o grande problema, um dos problemas cruciais das Democracias modernas.

O que parece evidente é que a crise da Democracia - e não é somente a crise da Democracia brasileira - se cifra precisamente na crise da representação política. Os regimes ditos "representativos" carecem de representatividade.

Algum erro existe no processo da influência da vontade do povo nos órgãos deliberativos do Governo. 
Diante dessa evidência, Georges Burdeau exclama: "Na idade da desagregação do átomo, estamos ainda, no plano constitucional, a praticar as técnicas mais arcaicas" (...) "Esse conformismo, que se considera habitualmente como característico das sociedades primitivas, constitui um dos fatores mais ativos da crise de que sofrem as instituições democráticas" (Tratado de Ciência Política, Tomo IV, 111).

Pelo sistema tradicional, todos os eleitores são igualados uns aos outros. Todos, no dia da eleição - como já foi assinalado - valem exatamente o mesmo: cada um vale um voto. Mas grita aos céus que essa homogeneidade, essa unidade, não existe. Não passa de uma pura ficção. Fábio Konder Comparato disse: "não é preciso grande esforço de raciocinio nem excepcional acuidade de análise para perceber o irrealismo dessa noção simples e unitária de povo: ele não é, nunca, uma coleção de individuos iguais entre si, mas um conjunto complexo de classes, raças, clãs, estamentos, grupos religiosos, cujo poder e influência variam enormemente, de época a época e de país a pais. O mecanismo de atribuição do poder supremo a essa unidade global e abstrata, por meio da expressão do voto majoritário, mais esconde do que revela a realidade do poder efetivo da sociedade" (Para viver a democracia, $2^{a}$ parte, $\mathrm{O}$ conceito de povo). Que sentido tem o voto igualitário, para a produção de um regime verdadeiramente representativo? O deputado ou o senador, eleito por esse voto, será, de fato, um representante político de seus eleitores? Que relação existirá entre o eleito e a vida real do eleitor? Passado o momento glorioso da votação, poderá o eleitor, ao voltar para a sua casa e para o ramerrão de seus dias, ou para as aflições de sua vida quotidiana, dizer, em sã consciência, que ele está representado nos órgãos do Poder Legislativo do Estado?

Em verdade, no regime vigente, o voto, uma vez colocado na urna, perde paternidade e vinculação.

Sobre esse assunto, escreveu Fábio Konder Comparato: "Em todos os quadrantes vem sendo sentida a deficiência da representação popular fundada no voto individual. Do lado dos representados, verifica-se que o sistema dificilmente exprime os únicos interesses que valem em matéria política: os interesses sociais. Do lado dos representantes, estes tendem a aparecer como veículos de um vago e indefinido interesse geral, quando na verdade procuram esconder sua efetiva vinculação a interesses sociais bem definidos. Sem falar na facilitação que o sistema enseja à política de clientela pessoal, pela distribuição de vantagens individuais aos eleitores" (Brasil. Sociedade Democrática, trabalhos de diversos autores, Seção VI, "Um Quadro Institucional para o Desenvolvimento Democrático" 21).

Contra essa deficiência, o anseio de uma Democracia mais verdadeira se tem manifestado, modernamente, contra o velho equívoco de pensar que cada congressista, no Poder Legislativo, seja representante de todo o povo. Fato curioso! A reação do espírito democrático, no mundo moderno, está sendo assinalada pela abertura, junto aos Parlamentos, ou longe deles, de novos canais, para a livre penetração das pretensões autorizadas da sociedade, nos órgãos planejadores do Governo.Observe-se que, nos novos tempos, tudo parece se encaminhar, aproximadamente, para a solução 
que acaba de ser apontada. Tudo, na consciência política das classes atuantes do Brasil moderno, parece tender para processos de uma Democracia social, que se convencionou chamar de Democracia Participativa.

De fato, hoje, sem nenhuma interferência de partidos políticos e de parlamentares, já são freqüentes as reuniões dos representates de categorias diversas de trabalhadores e de empresários com os ministros do Governo e seus assessores, para planejamentos da política econômica. Já são usuais, por iniciatva do próprio Governo, as chamadas mesas do entendimento, para a sincera tentativa de composição de interesses sociais conflitantes. A legitimidade de muitas decisões oficiais começa a depender da adesão que lhes é dada pelos grupos sociais a que elas interessam.

Essa reação se manifesta na evolução do próprio conceito de povo. A imagem do povo uno e homogêneo vem sendo completada por uma visão realista da sociedade. Aquela imagem tende a ser substituída por uma noção do povo real, do povo heterogêneo, feito de grupos sociais diferenciados e de categorias diversas de profissionais. Conseqüientemente, além dos deputados, dos senadores e dos vereadores, começam a existir e a exercer pressão sobre os Governos, os representantes autênticos desses grupos e categorias, para a defesa dos interesses concretos de tais entidades.

Hoje, começa a ser predominante a convicção de que os grupos sociais devem ser reconhecidos e tratados como o que realmente são: matrizes e mananciais de muitas ordenações jurídicas da Nação. O papel dos grupos sociais, como produtores de normas e inspiradora de leis, e como forças de pressão, agindo sobre os Poderes Públicos, já não pode mais ser olvidado.

Saliente-se que a vontade dos governados, numa autêntica Democracia, não é uma abstração, uma fórmula oca, um recurso da demagogia. Numa autêntica Democracia, numa Democracia fundada na realidade das coisas, e não em mentiras ou ficções, a vontade dos governados não é uma quimérica e impossivel vontade nacional, mas, sim, em cada caso de ordenação legislativa, é a vontade do grupo social, ou dos grupos sociais, a que cada nova norma interessa.

No caso, por exemplo, de um projeto de lei sobre a carreira universitária, a expressão vontade dos governados significa, simplesmente, vontade dos grupos de governados, aos quais a carreira universitária diz respeito.

Em 1968, já Maria Eugenia diagnosticava: "Só é legitimo o regime que assegura a participação, nas decisões politicas direcionais, das forças que se desenvolvem nos grupos e circulos associativos de que se compõe a sociedade global" "O modelo da democracia moderna é a democracia pluralista" (Grupos de Pressão e Regime Representativo, 1" Parte, 2).

Num livro recente, mestre Paulo Bonavides, professor emérito da Universidade Federal do Ceará, assevera: "Democracia é o processo de participação dos governados na formação da vontade governativa" "Não há democracia sem

* Maria Eugenia Raposo da Silva Telles, LL.M. cm Dircito Público Comparado, da Cormell University, EUA; advogada pela Faculdade de Dircito da Universidade de São Paulo. 
participação. De sorte que a participação aponta para as forças sociais que vitalizam a democracia e lhe assinam o grau de legitimidade e eficácia no quadro social das relações do poder" (Teoria Constitucional da Democracia Participativa" Malheiros Editores, São Paulo, 2001).

8. A Emenda Constitucional necessária.

A pergunta que aqui se coloca é a seguinte: como se faria a permanente penetração da vontade dos grupos sociais nas decisões legislativas dos governantes?

Diante da questão crucial da democracia, não se queira procrastinar. Cumpre dar-lhe a resposta natural: o único meio de se fazer a permanente penetração da vontade dos grupos sociais nas decisões legislativas do Governo é o de se conferir a esses grupos o direito de iniciativa das leis que lhes dizem respeito.

É evidente que o recohecimento legal dessa irradiação normativa implicaria o abandono do mito do povo uno, do povo massa, e o reconhecimento da natural organização da sociedade, isto é, da natural divisão do povo nas comunidades ou grupos sociais de que ela é constituída.

De acordo com suas respectivas atividades, as comunidades se classificariam em categorias. Classificar-se-iam em categorias dos Ofícios e Profissões, da Indústria, da Agricultura, do Comércio, das Finanças, do Ensino Primário e Secundário, do Ensino Superior, do Ensino Técnico, das Letras e Artes, dos Esportes, das minorias...

Essas categorias se organizariam em quinze ou vinte entidades, que poderiam ser chamadas Instituições Representativas.

O elenco de tais instituições seria fixado pela lei. Mas elas permanecerian como organizações autônomas, independentes da estrutura administrativa do Estado. Integralmente custeadas com seus próprios recursos, em nada onerariam os cofres públicos. Exerceriam sua função de comunidades de base, irradiadoras naturais de normas para a disciplina de convivência humana.

Atribuir o direito de iniciativa de leis às Instituições Representativas é autorizar a apresentação de Projetos de Lei ao Congresso Nacional, pelos centros naturais de irradiação normativa, ou seja, pelas fontes espontâneas de normas daquelas normas nascidas no seio da sociedade, diretamente emanadas das simples realidades da vida. Atribuir-lhes tal direito é acrisolar, verdadeiramente, a participação da sociedade, na elaboração legislativa. É tornar efetivo "o encontro da Câmara com a sociedade" como disse Aécio Neves, que é presidente da Câmara dos Deputados .

Nota importante: é preciso não confundir o direito aqui preconizado (ainda não-consagrado na Constituição e ainda dependente de Emenda Constitucional), com o direito que a Constituição denomina "iniciativa popular" que "pode ser exercido pela apresentação à Câmara dos Deputados, de projeto de lei subscrito por, no mínimo, um por cento do eleitorado nacional, distribuido pelo menos por cinco Estados, com não menos de três décimos por cento dos eleitores de cada um deles" (art. 61 $\left.\S 2^{\circ}\right)$. 
É evidente que essa chamada iniciativa popular nada tem a ver com o ora pleiteado direito de iniciativa das Instituições Representativas. Aliás, nada impede que a Constituição atribua o direito de iniciativa das leis a essas duas muito diferentes fontes de normas.

Para apresentação de seus projetos ao Legislativo, e para sustentá-los perante os Poderes do Estado, as Instituições Representativas teriam Delegados credenciados, nomeados livremente pelas classes de suas respectivas categorias. Estes Delegados ou Mensageiros atuariam como procuradores, com os poderes e obrigações do mandato imperativo. Seriam contratados e pagos pelas próprias instituições. Agiriam sempre para um fim certo; específico e declarado. E, em cada caso, uma vez terminada a missão para que tenham sido contratados, seriam desconstituídos.

Com as Instituições Representativas, com seus Delegados ou Mensageiros credenciados, abrir-se-iam canais desimpedidos para a penetração da vontade dos governados o pensamento do povo nas decisões legislativas dos governantes.

Pois bem, o que agora se propõe é a criação de um Plenário, em que os Mensageiros das Instituições Representativas possam se encontrar com membros credenciados dos Poderes do Estado, para a exposição franca, a livre discussão de pretensões e de dificuldades; para a defesa do que fosse considerado direito e equiitativo, e para a condenação do que fosse tido como injusto ou iníquo - tudo num grande esforço conjunto, em busca de soluções satisfatórias e possíveis.

Desses encontros diretos, haveriam de surgir, de certo, soluções benfazejas ou razoáveis, atalhadoras de conflitos e greves. Deles adviriam, em momentos cruciais, decisões urgentes, capazes de orientar, muitas vezes, a ação do Executivo.

O que se alvitra é que esse Plenário seja uma ágora, um consistório, um átrio - o fórum no qual as Instituições Representativas pudessem exercer, por meio de seus delegados ou mensageiros, o direito de iniciativa das leis.

Atenção! Acaba de ser criada, na Câmara dos Deputados, por obra de seu presidente, deputado Aécio Neves, a Comissão de Legislação Participativa.

Alvissareira novidade! Tal Comissão, talvez, possa constituir-se naquele Plenário, naquele fórum ideal, para o desempenho da missão atribuída aos inencionados delegados ou mensageiros, e para a apresentação dos Projetos de Lei das Instituições Representativas.

O nome dado a essa Comissão a define. Denota o sentido da Reforma Política que ela preconiza. Revela a intenção de conferir autenticidade e realismo à representação política. Prenuncia o propósito de substituir as ficções de uma Democracia do "faz-de-conta" pela Democracia Participativa

Justificando a criação da sua Comissão, disse o deputado Aécio Neves: "Entendemos que a reaproximação com a sociedade requer, sobretudo, participação direta do povo no processo legislativo. Criamos para esse fim, a Comissão de Legislação Participativa. Não é apenas mais uma comissão permanente, mas uma comissão singular e única, que permitirá a projetos oriundos de entidades da sociedade - 
sindicatos, ONGs, associações de bairro, etc. - se aprovados na comissão, virar lei. A comissão encontra-se em franco funcionamento" (Folha de S. Paulo, de $1^{\circ}$ de janeiro de 2002)

Sinal dos tempos! Manifestação auspiciosa!

Numa crônica na Folha de S. Paulo, publicada em 28 de outubro de 1996, o jornalista Josias de Souza escreveu: "O Brasil é um país por fazer: Para fazêlo, exige-se alguém capaz de sonhar com o impossivel"

Ao delinear uma Democracia autêntica para o Brasil, estar-se-á sonhando, acaso, com o impossivel? Quem sabe? Mas o certo é que esse é o sonho que mostra o caminho.

"Ao Editor,

com o abraço e a saudação do velho estudante."

São Paulo, junho de 2002. 